\title{
Gills of Juvenile Fish Piaractus mesopotamicus as Histological Biomarkers for Experimental Sub-lethal Contamination with the Organophosphorus Azodrin ${ }^{\circledR} 400$
}

\author{
Cácia Aparecida Mendes Rudnicki ${ }^{1}$, Gisele Cristiane Melo $^{1}$, Lucélia Donatti ${ }^{2 *}$, Helena \\ Gonçalves Kawall ${ }^{3}$ and Edith Fanta "in memoriam" \\ ${ }^{I}$ Universidade Federal do Paraná; Curitiba - PR - Brasil. ${ }^{2}$ Departamento de Biologia Celular; Universidade \\ Federal do Paraná; C. P.: 19031, 81531-970; Curitiba - PR-Brasil. ${ }^{3}$ Centro Universitário Campos de Andrade; \\ Curitiba - PR - Brasil
}

\begin{abstract}
Piaractus mesopotamicus is a freshwater native fish from rivers of the Paraná-Paraguay Basin and of the Pantanal region and has been used for repopulation programs in Brazil. Juvenile fishes were exposed to the sub-lethal dose of $1.08 \mathrm{mg} / \mathrm{L}$ of the OP Azodrin ${ }^{\circledR} 400$ containing $0.43 \mu \mathrm{L} / \mathrm{L}$ of the active principle monocrotophos for $96 \mathrm{~h}$. A frequent pathology in the gills at all times of exposure was epithelial detachment, from minimal until $24 \mathrm{~h}$ of exposure, to intense after $48 \mathrm{~h}$ of contamination. Deformed pillar cells in the respiratory lamellae leading to irregular blood spaces and blood congestion, as well as hyperplasia and lamellar fusion were observed. These histopathologies suggested that $48 \mathrm{~h}$ after $T_{0}$ was an important time when a reduction in the capability for gaseous exchange with consequent weakening of the fishes' condition could occur. This could impair growth and development of juveniles introduced in water bodies for repopulation programs.
\end{abstract}

Key words: Freshwater Fish; Organophosphorus; Monocrotophos; Morphology; Branchiae

\section{INTRODUCTION}

Among the known pesticides, organophosphates (OPs) are extensively used in agriculture all over the world (Pehkonen and Zhang, 2002; Rodrigues and Fanta, 1998; Saleha Banu et al., 2001; Samuel and Sastry, 1989; Sogorb and Vilanova, 2002; Thangnipon et al., 1995).

The OP used in this study was Azodrin ${ }^{\circledR} 400$ that contained the active principle monocrotophos. Azodrin ${ }^{\circledR} 400$ belongs to the toxicological class II, being considered highly toxic to birds, bees, and aquatic organisms (Cavero 1982; Gelmini et al.,
1986; Cheremisinoff and King, 1994; Larini, 1999; Ramos 1999; SEAB, 2002). It is used in cotton, beans, soy, corn, maize, peanuts, coffee and potato plantations (Ramos, 1999; SEAB, 2002). This OP is widely used in the state of Paraná (Brazil) as is reported by the Secretariat of Agriculture and Supply of the State Paraná. These plantations are usually near to freshwater bodies such as rivers and lakes that contain rich aquatic biodiversity. Contamination of the water bodies occurs mainly by aerial pulverization, accidental spills, and rain water drainage. Therefore, nontarget aquatic animals may be exposed to the

*Author for correspondence: donatti@ufpr.br 
insecticide in levels that can vary from sub-lethal to acute and lethal (Thangnipon et al., 1995).

According to Fanta et al. (2003) many pesticides that remain at sub-lethal levels in the aquatic environment for shorter or longer periods are not detected because they do not cause the immediate death of fish. However, at sub lethal levels, OP pesticides can change significantly some physiological and biochemical processes, and even the morphology of several tissues when they enter the fish organism (Silva et al, 1993; Sancho et al., 1992).

Fish gills are sensitive to many classes of chemical pollutants dissolved in water because they are in direct contact with the aquatic environment, and any damage in their structure can interfere with respiration and the ionic homeostasis (Machado and Fanta, 2003; Van den Heuvel et al., 2000).

Histological alterations constitute excellent biomarkers of exposure to toxicants because they represent the result of biochemical and physiological changes (Hinton et al., 1989). The most common injuries in gills are epithelial detachment (Machado and Fanta, 2003; Mallatt, 1985; Richmonds and Dutta, 1989; Schwaiger et al., 2004), hyperplasia (Annune and Ajike, 1999; Dutta et al., 1993; Fanta et al., 2003; Oliveira Ribeiro et al., 1996), fusion of secondary lamellae (Capinpin, 1994; Karan et al., 1998; Thophon et al., 2003) and aneurysm (Stentiford et al., 2003; Thophon et al., 2003; Van den Heuvel et al., 2000).

Piaractus mesopotamicus is a freshwater native fish from tropical and subtropical rivers of the Paraná-Paraguay Basin and from flooded areas of the Pantanal region (State of Mato Grosso, Brazil) (Severi et al., 1997; Lima et al, 1998). Adults that may weigh up to $20 \mathrm{~kg}$ become target of sport fishery or are kept in fish farms for fish-and-pay activities (Projeto Pacu, 2003). There is also a program for the introduction of juvenile fish reared in fish farms into rivers, in order to raise the levels of fish populations and to guarantee that there is enough fish for commerce and for game.

Therefore, the present work had the aim of using $P$. mesopotamicus juveniles' gills as biomarkers, to study the morphological alterations which could occur in the branchial tissue after acute exposure to sub-lethal concentrations of monocrotophos. The results obtained from the bioassays might help to understand the effects of this OP on the health of individuals, and to foresee what would be the consequences of the presence of low concentrations of this product to the fish population.

\section{MATERIALS AND METHODS}

\section{The experimental fish}

Juvenile freshwater fish $P$. mesopotamicus (Holmberg, 1887) (Pacu, Pacu-caranha or Caranha) ( $4.3 \pm 0.6 \mathrm{~cm}$ total length and $1.4 \pm 0.6 \mathrm{~g}$ weight) were obtained from a fish farm that provided a homogeneous sample of fish that had never been in contact with any kind of pollutant.

Fishes were acclimated for one week in several 37L aquaria filled with filtered, dechlorinated, constantly aerated tap water, and controlled environmental conditions (temperature $26.5^{\circ} \mathrm{C} \pm$ $1.0, \mathrm{pH} 7.4 \pm 0.25$, photoperiod $14 \mathrm{~h} \mathrm{light} / 10 \mathrm{~h}$ dark). All the individuals were fed once a day with commercial food.

\section{The product}

Azodrin ${ }^{\circledR} 400$ (BASF) is a commercial product that contains $40 \%$ of the active principle monocrotophos (phosphate of cis-(2methylcarbomol-1-methylvinyl)-dimethyl) and $60 \%$ of inert components. The technical product has two isomers: the isomere $\alpha$ that is biologically active and characterized as insecticide (SEAB, 2002) and the isomere trans that is inert (Mariconi, 1980). This highly toxic product has a strong smell, and displays a brownish colour, being soluble in water, acetone (Larini, 1999) and alcohol (Mariconi, 1980).

\section{Determination of the $\mathbf{L C}_{50}$}

After the acclimation period, 120 juveniles of $P$. mesopotamicus were exposed for $96 \mathrm{~h}$ to the following concentrations of monocrotophos: 2.4, $1.2,0.6$ and $0.3 \mu \mathrm{L} / \mathrm{L}$ (corresponding to $6.00 \mathrm{mg} / \mathrm{L}$, $3.00 \mathrm{mg} / \mathrm{L}, \quad 1.50 \mathrm{mg} / \mathrm{L}$ and $0.75 \mathrm{mg} / \mathrm{L}$ of Azodrin $\left.{ }^{\circledR} 400\right)$. All tests were carried out under a fume. The control group was kept uncontaminated. Each aquarium that was contaminated with one of the concentrations of monocrotophos contained 20 fishes, and there were also two control aquaria containing 20 fishes each. The static test followed a standardized protocol (ABNT, 1993; CETESB, 1990; Gherardi-Goldstein et al., 1990; IAP, 1997). The amount of monocrotophos was calculated according to the weight of fish contained in each aquarium. Fishes were fed once a day with 
commercial food and the abiotic conditions were the same as for acclimation.

All the fishes were alive after $96 \mathrm{~h}$ of exposure to concentrations lower than $0.6 \mu / \mathrm{L}$ of monocrotophos and no control fish died in the test. For the bioassays, a randomly chosen sub lethal dose of $0.43 \mu \mathrm{L} / \mathrm{L}$ of monocrotophos (corresponding to $1.08 \mathrm{mg} / \mathrm{L}$ of the commercial product Azodrin ${ }^{\circledR} 400$ ) was used.

\section{Bioassays}

Aquaria were contaminated with the sub-lethal dose of $0.43 \mu \mathrm{L} / \mathrm{L}$ of monocrotophos. Toxicity tests with 140 fishes were carried out under the same abiotic conditions as for acclimation.

$P$. mesopotamicus were contaminated at the initial time $\mathrm{T}_{0}$, and maintained in the same water for 96 h. The control group was kept uncontaminated for the same period.

Ten experimental fishes and 10 control fishes were sacrificed at each of the following times of exposure to the OP: 1, 4, 12, 24, 48, 72 and $96 \mathrm{~h}$ after $\mathrm{T}_{0}$.

\section{Histology}

For light microscopy (LM), the second right gill arch of P. mesopotamicus was sampled and fixed in Alfac $(16 \mathrm{~h})$, dehydrated in graded concentrations of ethanol, embedded in Paraplast Plus $^{\circledR}$, and $5 \mu \mathrm{m}$ sections were stained with hematoxylin and eosin (H.E.) (Clark, 1981). The images were captured with an Olympus photomicroscope connected to a computer that had the Image-Pro Express program. Histological features were identified, measured when appropriate and counted in relation to the number of lamellae. Only those secondary lamellae that were complete, from base to tip, were considered for analysis. For each experimental fish and control fish, 10 images containing 10 complete lamellae were analyzed.

For transmission electron microscopy (TEM), samples of the second left gill were fixed in Karnovsky (Culling et al., 1985), post-fixed in osmium tetraoxyde $2 \%$ in cacodylate buffer $0.2 \mathrm{M}$, $\mathrm{pH} 7.2$ for $1 \mathrm{~h}$. The material was contrasted in blocks with aqueous uranyl acetate $2 \%$, dehydrated in graded series of ethanol and embedded in Epon 812 resin (Luft, 1961). The ultra-thin sections were contrasted with uranyl acetate 2\% (Watson, 1958) and with a solution of lead nitrate (Reynolds, 1963). Micrographs were captured with an electron microscope JEOL 1200 EX II (Electron Microscopy Centre of the Federal University of Paraná).

\section{Statistical Analyses}

The numerical results obtained after evaluation of histopathologies, in all experimental periods, were compared with those of the control. Each experimental period was compared to all the others. The numerical results were expressed in mean \pm standard error. The statistical treatment of the results was carried out through ANOVA, followed by the Tukey test with $95 \%$ of significance for the comparison among the averages of the groups. For the non-parametric data, the Kruska-Wallis test with $95 \%$ of significance was applied. The level of significance adopted was $\mathrm{p}<0.05$.

\section{RESULTS}

Table 1 shows the results of test for determination of Azodrin ${ }^{\circledR} 400$

Table 1 - Concentrations of Azodrin ${ }^{\circledR} 400$ to determination of the $\mathrm{LC}_{50}$.

\begin{tabular}{lccccc}
\hline Dose Azodrin & $\mathbf{N}$ & Peixes & Mortos & & \\
\hline $0,00 \mathrm{mg} / \mathrm{L}$ & $\mathbf{0 h}$ & $\mathbf{2 4 h}$ & $\mathbf{4 8 h}$ & $\mathbf{7 2 h}$ & $\mathbf{9 6 h}$ \\
$6,00 \mathrm{mg} / \mathrm{L}$ & 0 & 0 & 0 & 0 & 0 \\
$3,00 \mathrm{mg} / \mathrm{L}$ & 0 & 0 & 5 & 8 & 10 \\
$1,50 \mathrm{mg} / \mathrm{L}$ & 0 & 0 & 0 & 0 & 1 \\
$0,75 \mathrm{mg} / \mathrm{L}$ & 0 & 0 & 0 & 0 & 0 \\
\hline
\end{tabular}

The gills of $P$. mesopotamicus had the structure reported for teleost fish. Each primary lamella had two rows of secondary lamellae. These were covered by squamous epithelial cells, sustained by pillar cells that presented cytoplasm flanges that enclosed the blood spaces (Fig. 1A, 2A). 
The following histopathologies were analysed and compared to the control gills (Fig. 1A): epithelium detachment (separation between the epithelium of the secondary lamella and the basal membrane showing interstitial fluid infiltration or oedema), classified as minimal (less than 50\% of detachment in one side of the secondary lamella), soft (less than $50 \%$ of detachment in both sides of the secondary lamella), moderate (more than 50\% of detachment in one side of the secondary lamella), severe (up to $50 \%$ of detachment in one side of the secondary lamella and less than $50 \%$ in the other), and intense (more than 50\% of detachment in both sides of the secondary lamella) (Fig. 1B,C); hyperplasia (proliferation of cells of the interlamellar epithelium and the respiratory epithelium); lamellar fusion (Fig. 1D); and aneurysm (dilation of the blood spaces showing congestion of blood cells, and damaged pillar cells).
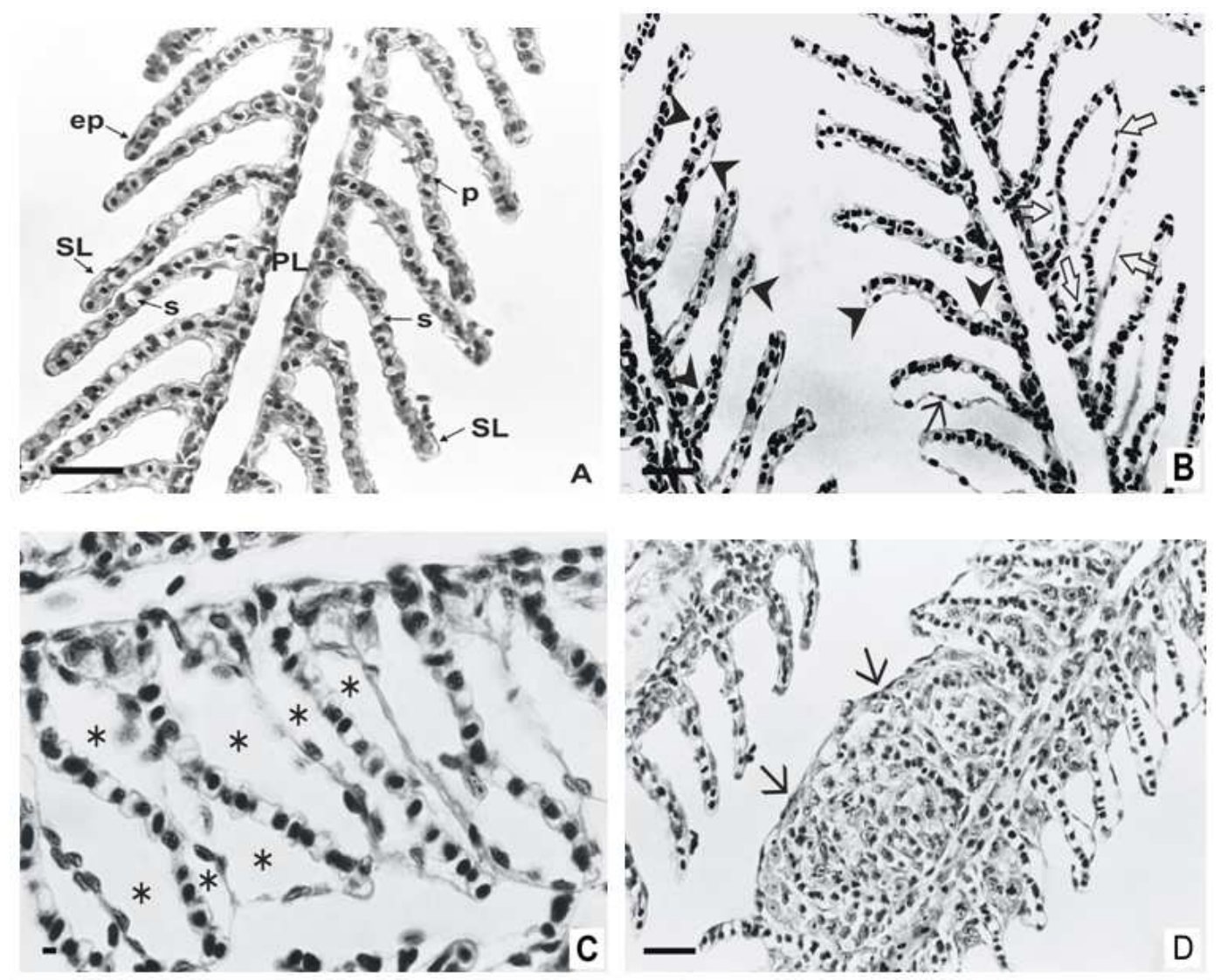

Figure 1 - Branchiae of Piaractus mesopotamicus (LM, staining H.E.). A - Control. Symbols: ep = epithelium; $\mathrm{SL}=$ secondary lamella; $\mathrm{s}=$ blood space; $\mathrm{p}=$ pillar cell; $\mathrm{PL}=$ primary lamella; bar $=10 \mu \mathrm{m}$. B, C and D - histopathologies. Symbols: arrow head = minimum detachment; white arrow = moderate detachment; $*$ = severe detachment; arrow = lamellar fusion and hyperplasia; bar $=10 \mu \mathrm{m}$.

After $24 \mathrm{~h}$ of exposure to the OP secondary lamellae started showing more frequent detachments of epithelia cells than in control gills, and also intracellular oedema (Fig. 2B). Oedema and detachments became severe after $48 \mathrm{~h}$ of exposure to the $\mathrm{OP}$ and epithelial cells were in a degenerative process. There was also a breakdown of pillar cells and disorganization of blood spaces (Fig. 2C, D). 

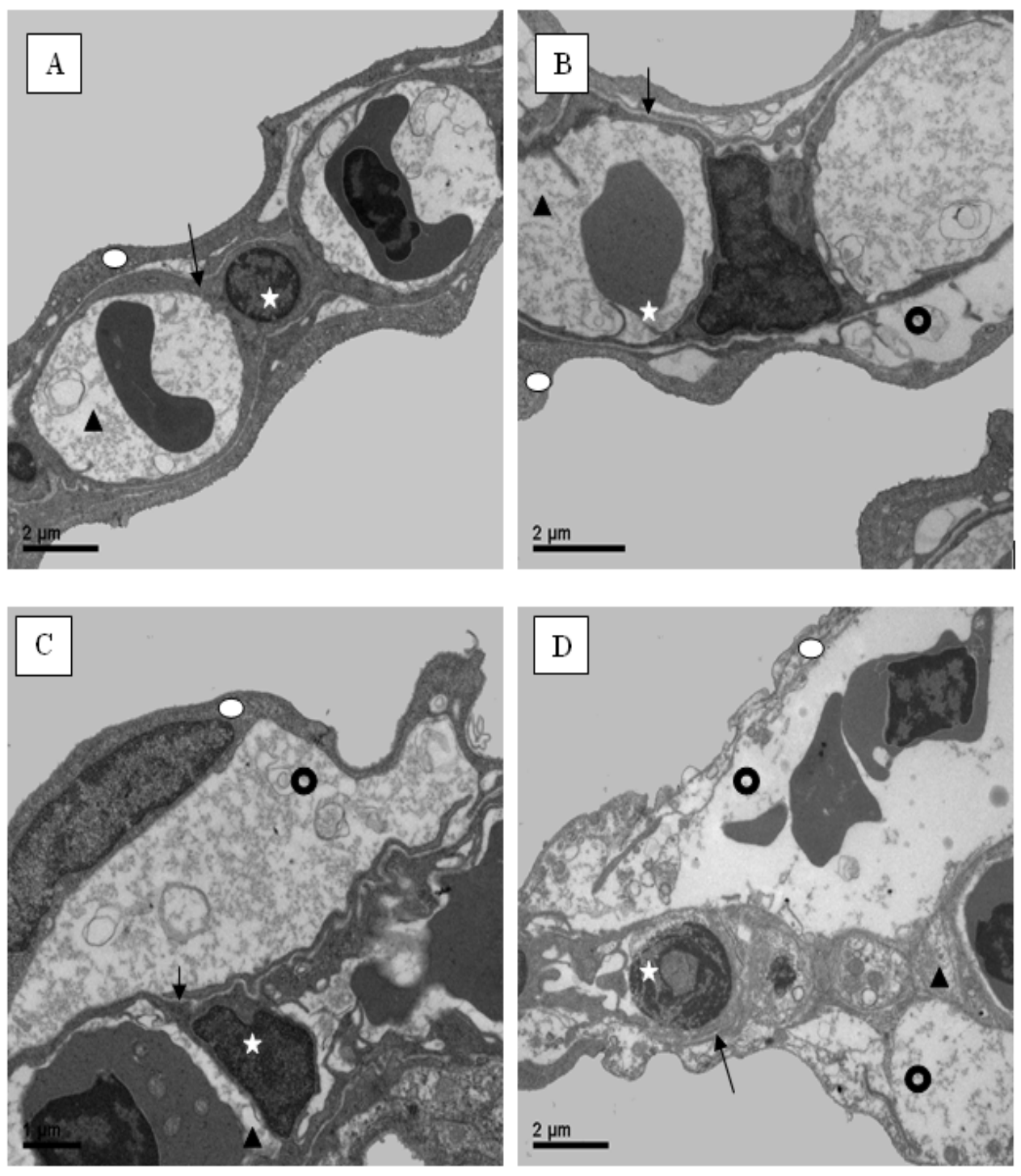

Figure 2 - Details of pillar cells and epithelium of Piaractus mesopotamicus in secondary lamellae. (TEM). A - control; B, C and D - Experimental. B - 24 h, C - 48 h and D $96 \mathrm{~h}$ after $\mathrm{T}_{0}$. Symbols: star $=$ pillar cells; arrow $=$ basal membrane; arrow head $=$ blood space; white dot = epithelial cell; circle = epithelial detachment with oedema.

The different levels of epithelial detachment and oedemas displayed, as consequence an increase of the distance between the external cell membrane of epithelial cells and the blood space in the secondary lamellae, if compared to the control lamellae (Fig. 3A). This became more serious from $24 \mathrm{~h}$ after $\mathrm{T}_{0}$ onwards and was extreme $96 \mathrm{~h}$ after $\mathrm{T}_{0}$ (Fig. 2D; 3D). In spite of this there were many regions of the secondary lamellae where the epithelium was still squamous (Fig. 3B, C, D). 

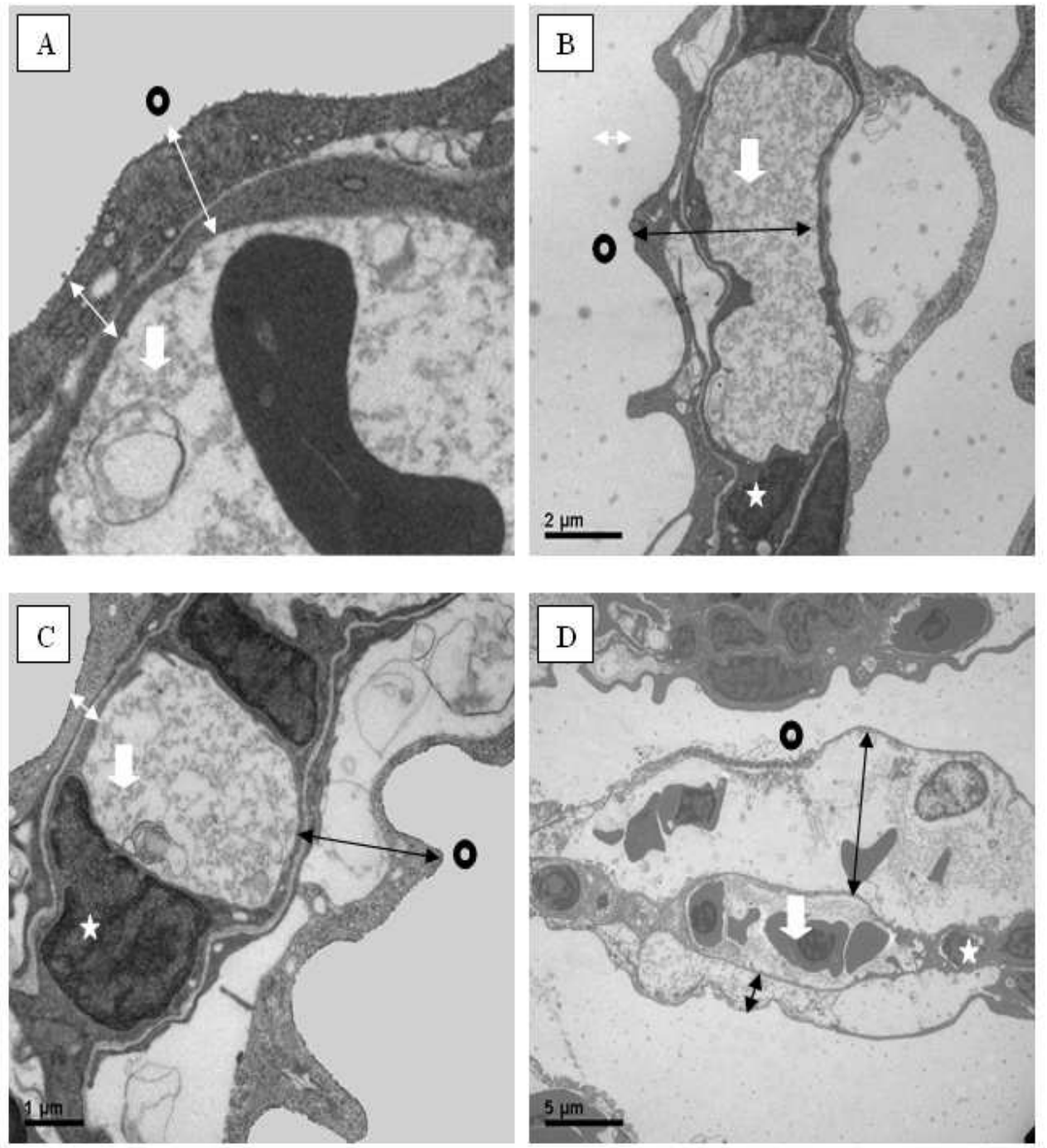

Figure 3 - Changes in the distance for dissolved oxygen diffusion (arrow with two heads) from water (circle) through epithelial cells to reach the blood space with erythrocytes (white arrow) surrounded by pillar cells (star) in Piaractus mesopotamicus. (TEM). A - control, B - 24, C - 48 and D - $96 \mathrm{~h}$ after contamination with the OP monocrotophos.

These changes occurred along the entire secondary lamellae (Fig. 4), leading to changes of blood spaces and congestion of blood cells $96 \mathrm{~h}$ after $\mathrm{T}_{0}$ (Fig. 4C, D).

Besides epithelial detachments, and oedema, other pathologies were hyperplasia, lamellar fusion,
(Fig. 1D) and aneurisms, that appeared from $4 \mathrm{~h}$ after $\mathrm{T}_{0}$ onwards, but in a very small proportion of secondary lamellae, and not in significantly different quantities among times of exposure (Fig. 5A, B, C, D). 

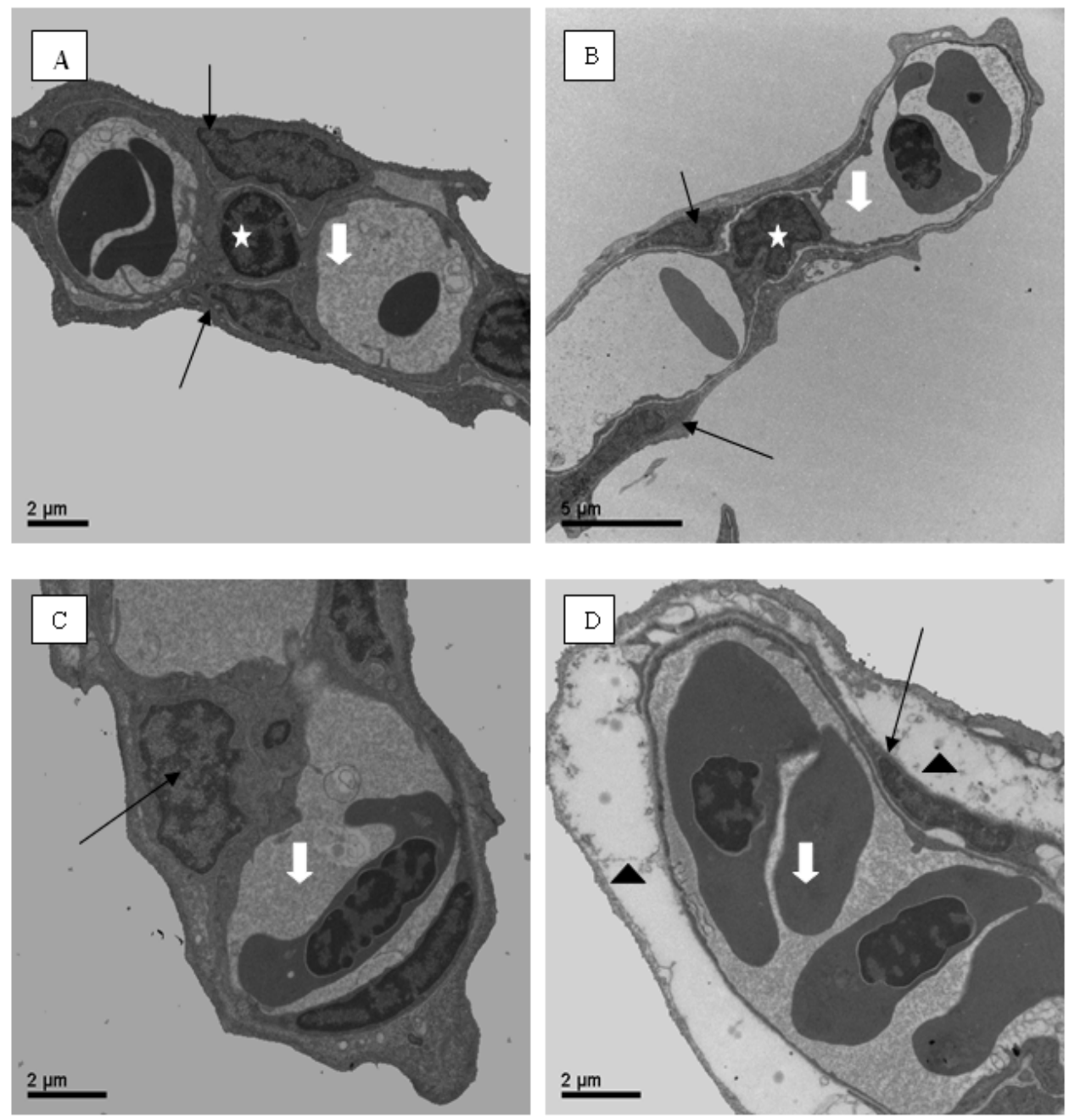

Figure 4 - Tip of secondary lamella in Piaractus mesopotamicus. (TEM). A - Control, B - 24, C and D $96 \mathrm{~h}$ after contamination with the OP monocrotophos. Symbols: star = pillar cell; white arrow = blood space containing erythrocytes; arrow head = epithelial detachment and oedema; thin arrow $=$ epithelia cell.

\section{DISCUSSION}

The $\mathrm{LC}_{50}$ of monocrotophos for P. mesopotamicus after acute exposure to the commercial product Azodrin ${ }^{\circledR} 400$ was between 1.2 and $2.4 \mu \mathrm{L} / \mathrm{L}$. Therefore, juveniles $P$. mesopotamicus were more susceptible to the presence of monocrotophos in the environment than some other species such as Oreochromis niloticus where the $\mathrm{LC}_{50}$ was $4.9 \mathrm{mg} / \mathrm{L}$ of monocrotophos (Thangnipon et al.,
1995), and Anabas testudineus where $\mathrm{LC}_{50}$ was even higher (19 mg/L) (Santhakumar et al., 1999). This shows the importance of studies with different species, including native species of regions potentially affected by OPs, because the level of sensitivity varies among them. It also shows that great care has to be taken to avoid contamination in regions where $P$. mesopotamicus occurs or may be introduced. 

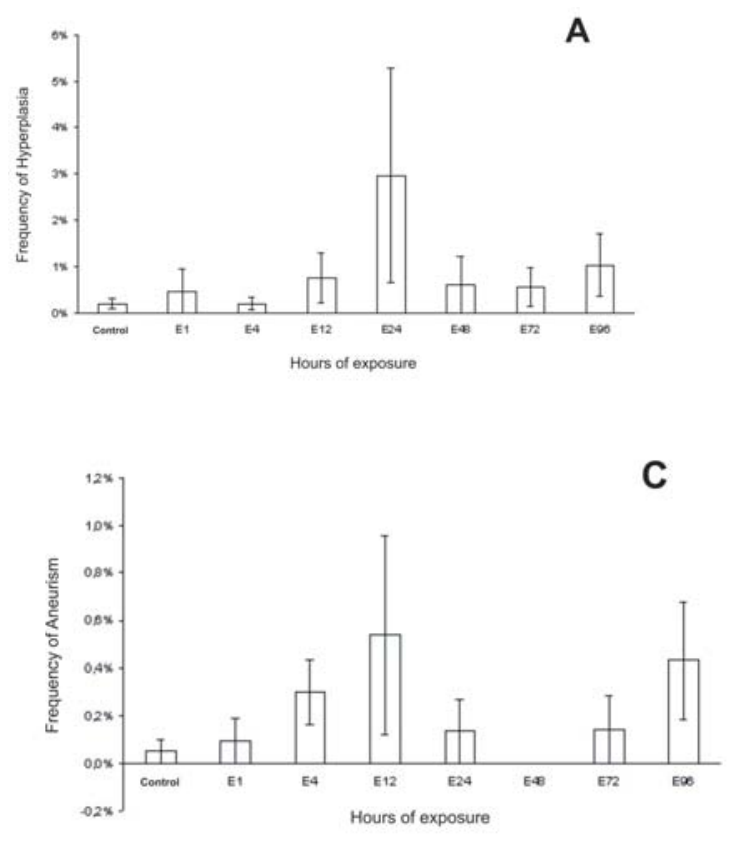
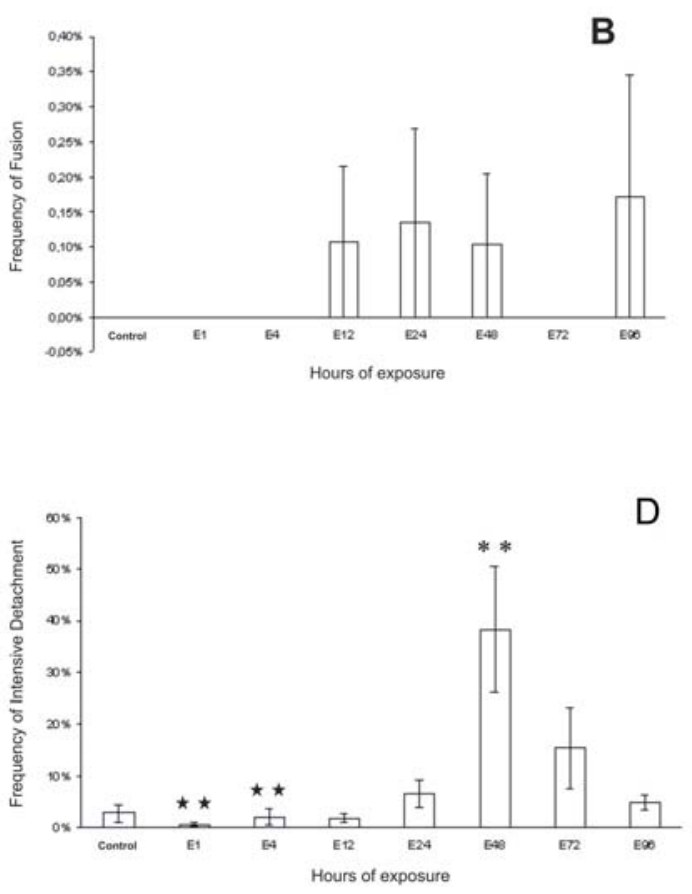

Figure 5 - Frequency of histopathologies in gills of Piaractus mesopotamicus exposed to sub lethal level of monocrotophos. A: hyperplasia; B: fusion of secondary lamellae; C: Aneurisms; D: Intensive epithelium detachment. (stars = significant difference $(\mathrm{p}<0.01)$ in relation to the $48 \mathrm{~h}$ group).

Morphological biomarkers are useful tools for the determination of the effect of pollutants on fish. Gills are considered the most vulnerable organ to the changes in the aquatic environment (Dutta et al., 1996), because they are in direct contact with the surrounding water that may contain OPs and, consequently, they are the first entrance door for these and other pollutants (Machado and Fanta, 2003). Detailed description of each pathology, mainly through electron microscopy, and the quantification of the pathologies observed in the gills of $P$. mesopotamicus in the present study allowed an evaluation of the degree of damage and the potential consequences for the fish. According to Bernet et al. (1999), a quantification of injuries in a histopathological investigation can be done through practicable statistics, but the morphological description of the injuries is essential and should be added to the quantification methods.

The epithelial detachment was the most frequent morphological alteration in the secondary lamellae in all tested times of exposure to monocrotophos.
In Mallatt's review (1985) the detachment of the epithelium was the most often described alteration. According to the author, this alteration occurs more in freshwater fishes than in marine fishes. This implies in an increase in the diffusion distance of oxygen, as seen in P. mesopotamicus that condition can affect the respiration of the fish, even resulting in their death (Dutta et al., 1993). Several studies have described acute exposure of fishes to other OPs such as malathion (Capinpin, 1994; Richmonds and Dutta, 1989), diazinon (Dutta et al., 1993) and methyl parathion (Fanta et al., 2003; Machado and Fanta, 2003).

Considering that the extent of the epithelial detachments may be related to the seriousness of the consequences for the fish, they were described and classified in this study from minimal to severe and intense. The proportion of lamellae with severe detachment increased with the time of exposure, becoming more frequent $48 \mathrm{~h}$ after $\mathrm{T}_{0}$ onwards, but diminishing in frequency, $96 \mathrm{~h}$ after contamination. However, the extent of each detachment and of disorders of the epithelial cells 
was most impressive at that time. This was also observed by Richmonds and Dutta (1989) in Lepomis macrochirus after $48 \mathrm{~h}$ of exposure to the OP Malathion, and by Fanta et al. (2003) in Corydoras paleatus. This possibly occurs because freshwater fishes are hyperosmotic in relation to the environment, what favours the influx of water through the lesioned epithelium, increasing the hydropsy, and consequently the epithelial detachment (Machado and Fanta, 2003). Such condition increases the distance that the toxic substances have to travel to reach the blood stream, and therefore epithelial detachment could be considered as a defence mechanism against the entrance of excessive water pollutants after 48 hours of exposure (Dutta et al., 1993). Consequently, in $P$. mesopotamicus, there was a reduction in the number of branchial lamellae with intense detachment after $72 \mathrm{~h}$ of exposure to monocrotophos, probably because less pollutant entered the branchial epithelium, allowing a possible start of recovery of the epithelial tissue. The same was observed after $96 \mathrm{~h}$ of exposure to the OP methyl parathion in Corydoras paleatus (Fanta et al., 2003).

Hyperplasia of the epithelial cells was more frequent after $24 \mathrm{~h}$ of exposure. It was also observed in gills of fish which were contaminated with metals such as copper (Arellano et al., 1999), cadmium (Thophon et al., 2003), mercury (Oliveira Ribeiro et al., 1996), and with OPs such as diazinon (Dutta et al., 1993), dimethoate (Annune and Ajike, 1999), and methyl parathion (Fanta et al., 2003; Machado and Fanta, 2003). According to Machado and Fanta (2003) the cell proliferation in the interlamelar region reduces the respiratory surface and makes gaseous exchanges more difficult.

Fusion of secondary lamellae that was observed in the gills of the P. mesopotamicus resulted in an even higher reduction of the total respiratory area of the gills, and as a result, there was a reduction of the capacity of oxygen capture, causing hypoxia (Ojha et al., 1989; Karan et al., 1998). Fusion of secondary lamellae was equally observed in gills of Lepomis macrochirus after $72 \mathrm{~h}$ of exposure to the OP malathion (Richmonds and Dutta, 1989), as well as in fishes contaminated with metals such as mercury (Oliveira Ribeiro et al., 1996), copper (Arellano et al., 1999), or cadmium (Thophon et al., 2003).

Aneurysms were observed in few secondary lamellae of $P$. mesopotamicus gills. According to van der Heuvel et al. (2000), aneurysms in the branchial tissue probably result from the death of the pillar cells and, consequently, the loss of the structural integrity of secondary lamellae and the accumulation of blood cells. The pillar cells observed in $P$. mesopotamicus were morphologically modified slightly after 48 hours and intensively $96 \mathrm{~h}$ after exposure to the OP, and consequently the blood spaces became disorganized.

Hyperplasia, lamellar fusion and aneurysm were always higher in the experimental than in the control group, but the differences were not statistically significant, suggesting that the sublethal dose was in fact very low and did not cause extensive injuries to the branchial tissue of $P$. mesopotamicus.

Juvenile $P$. mesopotamicus exposed to sub lethal concentrations of the OP monocrotophos are, in comparison to other species, very sensitive to this product, being the sub lethal level was very low. The sub lethal concentration $0.43 \mu \mathrm{L} / \mathrm{L}$ is quite below $0.60 \mu \mathrm{L} / \mathrm{L}$ where no fish dyed after $96 \mathrm{~h}$ of contamination. It was randomly chosen for the present tests because the aim to detect if in such a low level of contamination there would still be seen morphological changes in the gills of the fishes, which could imply in consequences for their life fitness. As the present study has shown, this was the case.

The injuries observed in $P$. mesopotamicus gills were not exclusive for monocrotophos or OPs in general, but were noteworthy because they could result in at least temporary respiratory difficulties, which might affect the metabolism of several organs. Based on the present results, it could be suggested that $48 \mathrm{~h}$ after a sub-lethal contamination with monocrotophos, those was a critical moment for $P$. mesopotamicus juveniles, because several histopathology symptoms appeared or became more intense.

Considering that the fishes tested were juveniles and had not yet had the opportunity to reproduce, the high sensitivity to the product suggested that good care has to be taken in order to not eliminate the populations when this OP was used near to water bodies in which the species occured. Care should also to be taken when introducing these fishes in water bodies that eventually could become contaminated with OPs. 


\section{ACKNOWLEDGEMENTS}

The authors are grateful to $\mathrm{CNPq}$ (National Council for the Development of Scientific and Technological Research) for a Master stipend to Cássia Rudnicki and for the Productivity in Research Stipend for Edith Fanta.

\section{RESUMO}

Piaractus mesopotamicus é um peixe de água doce encontrado na Bacia Paraná-Paraguai e na região do Pantanal, tendo sido usado em programas de repovoamento no Brasil. Peixes juvenis foram expostos por 96 horas à dose sub-letal de $1.08 \mathrm{mg} / \mathrm{L}$ do organofosforado (OP) Azodrin ${ }^{\circledR} 400$ que contém $0,43 \mu \mathrm{L} / \mathrm{L}$ do principio ativo monocrotofós. A patologia frequiente nas brânquias foi o descolamento epitelial que variou de mínimo nas primeiras 24 horas a severo ou intenso após 48 horas de contaminação. Deformações e degeneração de células pilares nas lamelas respiratórias levando à formação de espaços sanguíneos irregulares e congestão sanguínea, hiperplasia e fusão lamelar também foram observadas. Sugere-se que 48 horas após o $\mathrm{T}_{0}$ é um tempo crítico após exposição a níveis subletais de OP, pois a capacidade de trocas gasosas poderá ter diminuído, levando ao enfraquecimento dos peixes. Os sintomas poderão prejudicar o desenvolvimento dos juvenis introduzidos em corpos de água em programas de repovoamento.

\section{REFERENCES}

ABNT - Associação Brasileira de Normas Técnicas (1993), NBR 12714: Água, Ensaio de toxicidade aguda com peixes, Parte I: Sistema estático, Rio de Janeiro.

Annune, P. A., Ajike, S. U. (1999), Acute toxicity and gill morphology of Oreochromis niloticus (Trewavas) exposed to Rogor. Journal of Aquatic Sciences, 14, 14.

Arellano, J. M., Storch, V., Sarasquete, C. (1999), Histological changes and copper accumulation in liver and gills of the senegales sole, Solea senegalensis. Ecotoxicology and Environmental Safety, B 44, 62-72.

Bernet, D., Schmidt, H., Meier, W., Burkhardt-Holm, P., Wahli, T. (1999), Histopathology in fish: proposal for a protocol to assess aquatic pollution. Journal of Fish Diseases, 22, 25-34.

Capinpin, E. C. (1994), Gill lesions in Nile tilapia Oreochromis fingerlings associated with acute Malathion poisoning. Philippine Journal of Science, 123 (4), 283-291.

Cavero, E. S. (1982), Inseticidas e acaricidas: Toxicologia, Receituário agronômico. Livroceres, Piracicaba.

CETESB - Companhia de Tecnologia de Saneamento Ambiental (1990), L5.019-I: Água, Teste de toxicidade aguda com peixes, Parte I, Sistema estático. São Paulo.

Cheremisinoff, N. P., King, J. A. (1994), Toxic Properties of Pesticides. Marcel Dekker, New York.

Clark, G. (1981), Staining Procedures. Williams and Wilkins, Baltimore.

Culling, C. F. A., Allison, R. T., Barr, W. T. (1985), Cellular Pathology Technique. Butterworth, London.

Dutta, H. M., Richmonds, C. R., Zeno, T. (1993), Effects of diazinon on the gills of bluegill sunfish Lepomis macrochirus. Journal of Environmental Pathology, 12 (4), 219-227.

Dutta, H. M., Munshi, J. S. D., Roy, P. K., Singh, N. K., Adhikari, S., Killius, J. (1996), Ultrastructural changes in the respiratory lamellae of the catfish, Heteropneustes fossilis after sub lethal exposure to malathion. Environmental Pollution, 92 (3), 329-341.

Fanta, E., Rios, F. S., Romão, S., Vianna, A. C. C., Freiberger, S. (2003), Histopathology of the fish Corydoras paleatus contaminated with sub lethal levels of organophosphorus in water and food. Ecotoxicology and Environmental Safety, 54, 119130.

Gelmini, G. A., Novo, J. P. S., Zamariolli, D. P. (1986), Coletânea de Portarias e Informações gerais sobre defensivos agrícolas e receituário econômico. CATI, Campinas, p. 221.

Gherardi-Goldstein, E., Bertoletti, E., Zagatto, P. A., Araújo, R. P. A., Ramos, M. L. L. C. (1990), Procedimentos para Utilização de Testes de Toxicidade no Controle de Efluentes Líquidos, CETESB, São Paulo.

Hinton, D. E., Lauren, D. J., McCuskey, R. S., McCuskey, P. A., Clark Lantz, R. (1989), In vivo microscopy of liver microvasculature in rainbow trout (Oncorhynchus mykiss). Marine Environmental Research, 28, 407-410.

IAP - Instituto Ambiental do Paraná (1997), Manual de métodos para avaliação de toxicidade, Curitiba.

Karan, V., Vitorović S., Tutundžić, V., Poleksić, V. (1998), Functional enzymes activity and gill histology of carp after copper sulfate exposure and recovery. Ecotoxicology and Environmental Safety, B 40, 49-55.

Larini, L. (1999), Toxicologia dos praguicidas. Malone, São Paulo. 
Lima, J. A. F., Oliveira, B., Conlon, M. (1998), Purification and characterization of insulin and peptides derived from proglucagon and prosomatostatin from fruit-eating fish, the pacu Piaractus mesopotamicus. Comparative Biochemistry and Physiology. Oxford, 122, 27-135.

Luft, J. H. (1961), Improvements in epoxy resin embedding methods. Journal of Biophysical and Biochemical Cytology, 9, 409-414.

Machado, M. R., Fanta, E. (2003), Effects of the organophosphorous methyl parathion on the branchial epithelium of a freshwater fish Metynnis roosevelti. Brazilian Archives of Biology and Technology, 46 (3), 361-372.

Mallatt, J. (1985), Fish gill structural changes induced by toxicants and other irritants: a statistical review. Canadian Journal of Fisheries and Aquatic Sciences, 42, 630-648.

Mariconi, F. A. M. (1980), Inseticidas e seu emprego no combate às pragas: defensivos. Nobel, São Paulo.

Ojha, J., Rooj, N. C., Mittal, A. K., Munshi Datta, J. S. (1989), Light and scanning electron microscopic studies on the effect of biocidal plant sap on the gills of a hill stream fish, Garra lanta (Ham.). Journal of Fish Biology, 34, 165-170.

Oliveira Ribeiro, C. A., Fanta, E., Turcatti, N. M., Cardoso, R. J., Carvalho, C. S. (1996), Lethal effects of inorganic mercury on cells and tissues of Trichomycterus brasiliensis (Pisces; Siluroidei). Biocell (Mendoza), 20 (3), 171-178.

Pehkonen, S. O., Zhang, Q. (2002), The degradation of organophosphorus pesticides in natural waters: a critical review. Critical Reviews in Environmental Science and Technology, 32 (1), 17-72.

Projeto Pacú (2003), Information on pacú, at http://www.projetopacu.com.br.html.

Ramos, G. E. (1999), Compêndio de defensivos agrícolas. Andrei, São Paulo, 86-87.

Reynolds, E. S. (1963), The use of lead citrate at high $\mathrm{pH}$ as an electron-opaque stain in electron microscopy. Journal Cell Biology, 17, 208-212.

Richmonds, C., Dutta, H. M. (1989), Histopathological changes induced by malathion in the gills of bluegill Lepomis macrochirus. Bulletin of Environmental Contamination and Toxicology, 43, 123-130.

Rodrigues, E. de L., Fanta, E. (1998), Liver histopathology of fish Brachydanio rerio HamiltonBuchman after acute exposure to sub lethal levels of the organophosphate Dimethoate 500. Revista Brasileira de Zoologia, 15 (2), 441-450.

Saleha Banu, B., Danadevi, K., Rahman, M. F., Ahuja, Y. R., Kaiser, J. (2001), Genotoxic effect of monocrotophos to sentinel species using comet assay. Food Chemical Toxicology, 39 (4), 361-366.

Samuel, M., Sastry, K. V. (1989), In vivo effect of monocrotophos on the carbohydrate metabolism of the freshwater snake head fish, Channa punctatus. Pesticide Biochemistry and Physiology, 34, 1-8.
Sancho, E., Ferrando, M. D., Gamon, M., AndreuMoliner, E. (1992), Organophosphorus diazinon induced toxicity in the fish Anguilla anguilla L. Comparative Biochemistry and Physiology, C 103 (2), 351-356.

Santhakumar, M., Balaji, M., Ramudu, K. (1999), Effect of sub lethal concentrations of monocrotophos on erythropoietic activity and certain hematological parameters of fish Anabas testudineus (Bloch). Bulletin of Environmental Contamination and Toxicology, 63, 379-384.

Schwaiger, J., Ferling, H., Mallow, U., Wintermayr, H., Negele, R. D. (2004), Toxic effects of the nonsteroidal anti-inflammatory drug diclofenac Part I: Histopathological alterations and bioaccumulation in rainbow trout. Aquatic Toxicology, 68, 141-150.

SEAB(2002), http://www.pr.gov.br/agrotoxico/

Severi, W., Rantin, F. T., Fernandes, M. N. (1997), Respiratory gill surface of the serrasalmid fish, Piaractus mesopotamicus. Journal of Fish Biology, 50, 127-136.

Silva, H. C. da, Medina, H. G. S., Fanta, E., Bacila, M. (1993), Sublethal effects of the organophosphate Folidol 600 (Methyl parathion) on Callichthys callichthys (Pisces, Teleostei). Comparative Biochemistry and Physiology, 105 C (2), 197-201.

Sogorb, M. A., Vilanova, E. (2002), Enzymes involved in the detoxification of organophosphorus, carbamate and pyrethroid insecticides through hydrolysis. Toxicology Letters, 128, 215-228.

Stentiford, G. D., Longshaw, M., Lyons, B. P., Jones G., Green, M., Feist, S. W. (2003), Histopathological biomarkers in estuarine fish species for the assessment of biological effects of contaminants. Marine Environmental Research, 55, 137-159.

Thangnipon, W., Thangnipon, W., Luangpaiboon, P., Chinabut, S. (1995), Effects of the organophosphate insecticide, monocrotophos, on acetylcholinesterase activity in the Nile Tilapia fish (Oreochromis niloticus) Brain. Neurochemical Research, 20 (5), 587-591.

van den Heuvel, M. R., Power, M., Richards, J., Mackinnon, M., Dixon, D. G. (2000), Disease and gill lesions in Yellow Perch (Perca flavescens) exposed to oil sands mining-associated waters. Ecotoxicology and Environmental Safety, B 46, 334341.

Watson, M. L. (1958), Staining of tissue sections for electron microscopy with heavy metals. Journal of Biophysiology and Biochemistry Cytology, 4 (4), 475478.

Received: August 22, 2007; Revised: April 04, 2008; Accepted: March 27, 2009. 